\title{
A Conceptual Framework to Enable the Changes Required for a One-Planet Future
}

Maria Honig, Samantha Petersen, Tom Herbstein, Saul Roux, Deon Nel, Clifford Shearing

\section{Abstract}

We conceptualise a framework that incorporates psychological and non-psychological factors influencing pro-environmental behaviour. We conducted qualitative investigations in five sectors in South Africa, where individuals and groups are dealing with significant environmental issues, including climate change, biodiversity loss and land-use change. We found three fundamental elements necessary for behavioural change to be realised: awareness (A) is defined as an understanding that society and earth systems are connected; motivation (M) involves the personal and operational drivers that encourage an individual or organisation to respond to new levels of awareness; and pathways (P) recognise the practical solutions and opportunities that facilitate actual change. AMP was built up from 38 variables that cut across between three and five of the case studies, which were further grouped into 14 categories. The inter-connectedness of AMP suggests that for pro-environmental behaviour to occur, attention cannot be focussed on satisfying one of the elements in isolation. This is the first attempt to integrate theory from social psychology, sociology, organisational theory, and management in a conceptual framework for proenvironmental behaviour. The AMP framework is useful for supporting practitioners or change agents designing environmental sustainability initiatives. 
Keywords: pro-environmental behaviour, conceptual framework, South Africa, case studies, change

\section{Introduction}

The environmental challenges facing the planet and humanity have been widely reported (Barnosky et al., 2012; Rockström et al., 2009). Critical to solving this challenge is shifting behaviour to engage earth systems more pro-environmentally. Pro-environmental behaviour typically refers to "behaviour that harms the environment as little as possible, or even benefits the environment" (Steg and Vlek, 2009: 309). However, in this study we broaden the term to also describe a deeper connection between human well-being (including social and economic well-being) and ecosystem health.

A number of frameworks for changing behaviour have been proposed, including several attempts to describe the factors that result in pro-environmental behaviour (PEB) (Ajzen and Fishbein, 1980; Bamberg and Schmidt, 2003; Darnton, 2008; Hines et al., 1987; Kollmuss and Agyeman, 2002; Schwartz, 1977; Stern, 2000). These studies use sociological as well as psychological factors to explain pro-environmental behaviour or the lack thereof (Abrahamse et al., 2005; Ajzen and Fishbein, 1980; Bamberg and Möser, 2007; Heberlein, 1977; Hines, et al., 1987; Kollmuss and Agyeman, 2002; Lehman and Geller, 2005; Ramsey and Rickson, 1976; Schultz et al., 1995; Steg and Vlek, 2009; Stern, 2000). The most notable examples are the Theory of Planned Behaviour (Ajzen, 1985) - based on an earlier model, the Theory of Reasoned Action (Ajzen and Fishbein, 1980) - and the related 'ABC' framework of 
behaviour change (Shove, 2010), the Model of Concern (Stern et al., 1995), later developed into the Values-Beliefs-Norms (VBN) theory of environmentalism (Stern, 2000), and the Norm Activation Theory (NAT) (Schwartz, 1977). A shortcoming of these psycho-social models is that they do not address some of the key external factors, such as political, institutional and physical influences, which also drive or determine behaviour (Gifford, 2008; Shove, 2010). Many non-psychological factors for driving pro-environmental behaviour have been well studied, for example factors such as agency (Bandura, 1989), opportunity (Michie et al., 2011) and innovation (Rogers, 1962). The limitations of these studies are that they in turn do not adequately incorporate the importance of attitudes, beliefs, values and norms, i.e. the concepts that are mostly explored in environmental psychology.

There is, thus, a clear need to develop theories and models that incorporate concepts and ideas across disciplines and to explore the relationships between them, both to inform theory and to guide practitioners (Castro, 2006; Darnton, 2008; Stern et al., 1993; Stern, 2000; Steg and Vlek, 2009; Wilson et al., 2009). Some authors have attempted to do this but the field remains relatively under-studied. For example, Fransson and Gärling (1999) reviewed behavioural change studies that have attempted to show correlations between determinants, such as socio-demographic and/or psychological factors, and environmental concern. They found that the effect of background factors are weak and that the factors with the largest effect on behaviour appear to be knowledge, internal locus of control (positive control beliefs), personal responsibility, and perceived threats to personal health. This review proposed a new framework integrating some of their previous research. Vlek (2000) conceptually models environmental problem-solving using a variety of approaches 
emanating from different disciplines, thereby identifying six lines of psychological research, which range from environmental attitudes to environmental policy-decision support systems. Vlek (2000) criticises mainstream psychology and provides some suggestions for resolving the lack of cross-fertilisation with other disciplines. He accuses the field of being too anthropocentric and functionalistic, leaving policy makers with little or no background in psychology without any toe-holds when developing policy. He recommends that environmental psychology be added to environmentalism by: adopting multiple theory testing with multiple methods; analysing multiple levels (individual up to societal levels); and using multidisciplinary approaches. A further key model developed by Blake (1999), named the Value-Action Gap model, claims that models have not explored individual, social, and institutional constraints to action and automatically assume that humans are rational and make systematic use of the information available to them. His model identifies three barriers to action: individuality, responsibility, and practicality, further claiming that environmental concern can be outweighed by other conflicting attitudes.

Although these models have contributed to improving theory, they do not provide a framework for guiding the development of conservation initiatives to deliver environmental outcomes across contexts. Key trajectories of the socio-environmental challenges facing the planet are revealing negative trends, creating a feeling of urgency and importance. A number of authors have highlighted the need for the field (PEB) to have an increasing relevance to the real world, including a specific call to scientists and practitioners to better understand the science-practise interface. 
This article therefore sets out to conceptualise a framework of the main psychological and non-psychological factors that enable sustainable environmental behaviour across a wide range of contexts. The study specifically sought to answer the following questions:

1. What are the conditions under which humans will reshape the way they engage earth systems?

2. Are there over-arching conditions that are consistent across contexts?

3. Can these factors provide practitioners or change agents with a useful framework to guide the development of environmental sustainability strategies?

This article examines five institutions tackling significant environmental issues in South Africa and seeks to identify the determining factors enabling behaviour change in these cases, thereby building a framework, bottom-up, to formulate an environmental behaviour change framework that is a) applicable across contexts, b) integrates psychological and non-psychological factors, and c) supports practitioners or change agents design of environmental sustainability initiatives.

\section{Materials and Methods}

Pro-environmental behaviour can take a number of forms. In this study we look at two of them jointly, namely individual and collective. Individual pro-environmental behaviour is the action of one individual or a group of individuals intended to ameliorate or prevent environmental degradation. Collective action is undoubtedly 
linked to individual action, and it is conceived of here as the actions taken by large organisations (e.g. firms, non-governmental and governmental organisations) in their capacity as regulators of activities that impact on the environment. Each condition of pro-environmental behaviour is considered as an independent variable, as a measure of collective and individual level pro-environmental behaviour.

\section{Data collection}

Qualitative data were collected through a series of semi-structured interviews and focus groups, in five separate case studies, representing widely different contexts including: fishing, farming, food and beverage, finance and city-scale sustainable energy governance (hereafter titled local government). A total of 124 interviews were conducted (38 farmers, 15 fishers, 26 food and beverage staff, 15 local government actors and 30 financiers) between September 2012 and June 2013. Two focus groups were facilitated, one with six individuals, mostly academics with the research focus of re-connecting society with the environment, and the other with 11 individuals from the sectors under consideration. This amounts to a total of 254 hours of data collected in this study.

Semi-structured interviews facilitate the exploration of new ideas and gain rich insight, identifying related and non-related concepts to how change takes place in the specific contexts (Taylor-powell, 1998). However, there are inherent weaknesses and gaps in deriving data from interviews. Firstly, identifying the presence of individual values, beliefs and attitudes from the participants' responses may ignore the effects of culture, gender, and demographics. These contextual factors may impact on other variables 
and the overall understanding of motivational influences in the system. Secondly, data gained from interviews may need verification through using other approaches of theory testing, such as the triangulation of methods, as suggested by Conley and Moote (2003). For example, by conducting additional investigations and groundtruthing exercises, using mixed methods that are quantitative, one can further explore how changes in behaviour result in changes in the biophysical system. Thirdly, an intuitive process is required to extract a model for pro-environmental behaviour from the interviews, as it is not entirely self-evident at first attempt how to construct the major concepts from the data. Even so, this study benefited from a comparatively large sample size of qualitative data, giving a more robust proposition of concepts and ideas.

The sample size of interviews conducted allowed for a purposeful sampling strategy, called 'theory-based' or 'operational construct' sampling, which provides an effective way to explore manifestations of a theoretical construct of interest, so as to expand and analyse it. This strategy relies on selecting detailed cases that offer rich information to meet the purpose of conducting an in-depth analysis of the theoretical construct, thereby not aiming for representativeness or randomness, as with a standard sampling strategy (Taylor-powell, 1998).

The interviews included the following elements: i) background information about the actor and views of the actor on the environment and environmental challenges in their workplace; ii) existing cooperation and views on cooperation; iii) existing proenvironmental involvement and views about these pro-environmental interventions; iv) 'in principle' favourability to the idea of those interventions; v) broader views on 
the merits, drawbacks and constraints of pro-environmental interventions, and; vi) conceptions of pro-environmental behaviour, to give an indication of potential contextual influences on decision-making.

In exploring city-scale sustainable energy governance it was decided that a period of participant observation would be appropriate. Through participant observation, the researcher is embedded within a group with the aim of understanding group structures and dynamics, how a group operates, drivers of change and how such change affects the group (Neyland, 2008). It also allows for direct engagement with the social, political and cultural issues an institution faces (Atkinson and Hammersley, 1994). Such direct engagement and participation can provide a deep and detailed account of institutions and the drivers of institutional change (Mayoux, 2006). During the period of participant observation, detailed observations were recorded and transcribed in a field journal.

\section{Data analysis}

Interviews were transcribed verbatim and coded using coding criteria, which were progressively refined as coding took place, using a reflexive systematic iterative process (Layder, 1998). This approach consisted of consistent consultation of theory, reflexively comparing data and iteratively seeking trends to guide the distillation of conditions for change, termed by Layder (1998) as adaptive theory. Adaptive theory uses both inductive and deductive procedures for developing and elaborating theory (Layder, 1998). Adaptive theory's coding procedure, building on grounded theory's coding procedure, requires three steps: Pre-coding, which includes the initial 
organizing of paragraphs and concepts; provisional coding, which attaches concepts to theoretical ideas and notions; and core or satellite coding, which links concepts in a novel and systematic way, thereby refining theory. Data analysis identified key variables and grouped these into categories that are theorised in multiple disciplines, including sociology, psychology, behaviour theory, organisational theory and management science. These categories were in turn further grouped into macrovariables, based on their inter- and intra-relationships and further adaptive theorising. We label these macro-groupings as conditions for behaviour change.

\section{Background on five cases investigated in this study}

Five cases were chosen for our investigation. The cases are representative of the natural resource extraction, finance, and energy sectors in the South African context. We considered these three sectors to be the most influential institutions with respect to environmental challenges at a national level. These separate cases are not considered "successful" exemplars of sustainability but rather represent varying states of transition to sustainability, contributing to a more robust conceptual framework. For this reason, the independent variables were not only identified from those that reinforced pro-environmental behaviour, but also derived from those that were a barrier or constraint to pro-environmental behaviour, in other words, the reverse of an enabler/pathway. Additionally, in most cases where barriers to shifting behaviour were observed, there was evidence supporting the presence of the opposite condition, increasing our confidence in the results.

\section{Finance case}


New types of systemic risk emanating from deteriorating ecological systems is no longer a peripheral concern for this industry that can be simply addressed via Corporate Social Responsibility (CSR) innitiatives. Instead these risks are beginning to impact the finance industry's primary activities i.e. its need to generate wealth for clients and shareholders (Duncan, 2010; Morgan, 2013).

On the back of the growing concern of the state of ecological systems, particularly the effects of climate change, The Old Mutual Group, a large internationally-based financial services company, has embarked on a 'Responsible Business' (RB) journey (Old Mutual Plc., 2013). It seeks to contribute to strengthening the financial sector's relationship with ESG issues and to become more systemic, as an organisation, in addressing many of the interconnected challenges it faces. This case study explores some of the challenges and opportunities Old Mutual, as a member of the broader financial services industry, faces in implementing these strategies.

\section{Agricultural case}

In recent years, the responsibility of conserving biodiversity has gradually been taken up by private landowners of the Cape Floral Region as they have become more aware of its value (to them and to society) and the failure of mainstream natural resource management to address conservation needs (BWI, 2012). The Biodiversity and Wine Initiative (BWI) is a voluntary market-based initiative, which was designed to protect and conserve threatened natural heritage within the Cape Winelands, whilst maintaining productive viticulture through a collaborative effort by partnering the 
South African wine industry, the conservation sector, and WWF South Africa (BWI, 2012). The BWI is recognised as an exemplar of a 'successful' intervention as a result of widespread adoption and associated behavioural shift to biodiversity conservation in the viticulture sector (BWI, 2012; Pence, 2011). Of the 102,000 hectares currently planted to vineyards, another 130,717 hectares of the remaining natural areas are in private landowner conservation stewardship agreements with the BWI (BWI, 2012; CAPE, 2009; Pence, 2011).

\section{Fisheries case}

The Responsible Fisheries Alliance is a partnership between WWF South Africa and the four biggest fishing companies in South Africa, namely, Irvine and Johnston (I\&J), Sea Harvest, Oceana and Viking Fisheries. The intention of this initiative is to work with pivotal companies to proactively address some of the key challenges facing the sector and, in doing so, realise the following objectives: share information, expertise, and competencies to effect responsible fishing practices; influence fisheries governance; develop the skills of fishers and fisheries managers to implement ecosystem-based management; promote and implement independent high-quality research on the implementation of ecosystem-based management; establish effective engagement with market mechanisms (e.g. SASSI, MSC and retailers); and promote the image of responsible fisheries in the public space.

Food and Beverage case 
This case study explored a number of partnerships between WWF South Africa and the food and beverage sector, particularly South African retailers and a major beverage company, namely SAB. These partnerships were aimed at enabling these private sector corporations to respond to environmental challenges and to develop opportunities for creating more environmentally sustainable practices.

\section{Local government and energy case}

The energy challenge the City of Cape Town confronts is a strong representation of urban energy problems confronted in cities around the world. The City has committed to certain sustainable energy objectives that are framed within a range of policies and plans and has set up institutional structures for improving its energy governance. The City has already undertaken a range of renewable energy, energy efficiency and demand-side management projects and programmes (CCT, 2011). On the other hand, the City confronts a range of lock-ins and barriers to steering a more sustainable urban energy system. These include reliance on revenue from electricity sales, which act as a disincentive to support renewable energy and energy efficiency, regulatory barriers and institutional challenges.

\section{Results}

This study found a total of 38 variables cutting across between three and five of the cases, as listed in Table 1. These variables were grouped into 14 categories, namely, knowledge, experience, moral/personal norms, social norms, risk reduction/avoidance, profit motive, low-hanging fruits, leadership, resources, collaboration, technology and 
innovation, demonstration, incentives and regulation (Table 1). The variables and the differences between the cases are described further in the following paragraphs.

Knowledge or knowing and understanding the impacts of human behaviour on the environment were important factors in developing an intention to act. Knowledge was developed through formal interventions such as training, research and knowledgesharing processes and informally via the specific upbringing or first-hand experience through involvement in or exposure to that thing or event. Although both knowledge and experience were identified as important in all cases, the natural resource-based cases (fishing and farming) highlighted how early experiences (growing up 'at sea' or 'on the farm') fostered a particular understanding and view of being 'connected to nature'. Furthermore, first-hand experiences of environmental and economic-driven crises and threats, mostly originating in the macro environment, helped to shift actor framing and promote a greater understanding of the environmental challenges and risks affecting institutions. Actors in the finance sector suggested that the 2008 credit crisis led to a better understanding of a link between the generation of wealth and its impacts on sustainability in the wake of the crisis. There was concern that the industry was increasingly being held, publically, to account. Similarly, the first-hand experience of a farmer whose farm was impacted upon by an environmental hazard (e.g. fire, flood or extreme soil erosion) or prior experience with environmental management and conservation tended to have a better understanding of the risks that stem from the interface between the natural environment and their activities.

Most actors felt a moral responsibility towards human-induced impacts on the environment. The most frequent of these included beliefs of what is right and wrong; 
feelings that were both bad (e.g. guilt) and good (e.g. pride); and intrinsic valuedriven desires to be more pro-environmental. For example, many farmers and fishermen interviewed believed that they had a moral responsibility to preserve for future generations the natural ecosystems that support the resources on which they depend. By contrast, financiers found that the credit crisis fostered concerns among staff who felt they were no longer representing an industry highly regarded but one about which questions were being asked. Following on from this, social norms were present in a variety of ways applying pressures and developing motives among actors to be more pro-environmental. Institutionally the classification of social norms included a number of internal (within the organisation or group) and external (e.g. from market, competitors or public) drivers. Amongst these external drivers, the strongest desire amongst actors in all cases was the need to appear credible and to gain reputational value from operating or being seen to operate sustainably. The need to gain reputational value from pro-environmental behaviour was more important when the institution was small (e.g. farming) rather than large (e.g. finance and local government), as individuals are able to hide (or at least not publically identified) in large institutions and thus any negative reputational impacts do not affect them, personally, as much. A further important source of motivation revealed by actors was the drive to either reduce or avoid a risk. Risks from multiple sources from both the macro- and micro- environments drove pro-environmental behaviour in all cases. The desire to directly manage environmental risks was far stronger among the natural resource-based case studies (e.g. farming, fishing and food and beverage) than in those that do not rely directly on natural resources. While regulatory risks were observed to motivate almost all cases to tackle their environmental challenges, those specific to the case of local government and energy were the most complex and 
extensive in their nature, due to the observation of multiple conflicting or overly stringent regulations limiting pro-environmental behaviour. However, in all cases the profit motive featured strongly as a motivation for behaviour change. The profit motive often appeared to be deeply embedded in the organisations 'DNA', influencing many, if not most, of the ways the actors engage with their operating environment. In finance, awareness seems to be emerging of the deteriorating health of ecological systems and the systemic impact this may ultimately have on the industry's ability to generate profit. Conversely, in the case of local government, the role of revenue neutrality and the capacity to generate an operating surplus from electricity sales proved to be a fundamental disincentive driving municipal support for energy efficiency, distributed energy and improved energy management. Finally, easy choices and actions leading to pro-environmental behaviour were termed as a lowhanging fruits. The use of voluntary agreements motivated greater buy-in due to the non-binding nature of the agreement and actors could opt out whenever they felt the need to. This factor featured strongly among the farmers' motivation to join BWI, because they were already practicing most of what was required to join and the voluntary nature of the agreement made the option of joining much more attractive, as there was a highly regulatory climate of conservation contracts that already covered the landscape.

In all cases, action that was driven by a champion (an individual who drives proenvironmental behaviour irrespective of where they are placed in the hierarchy) and/or a leader (in this case an individual who has decision-making power and supports pro-environmental behaviour) greatly increased the uptake of solutions and mechanisms that promoted pro-environmental behaviour. Champions, by their nature, 
are able to spot gaps in the market, inefficiencies in systems, profitable opportunities, and new innovative solutions to operational challenges. In most instances, but most notably in local government, they were identified leaders who were able to convey the benefits of pro-environmental behaviour, which helped to raise awareness among other members of the organisation. Moreover, the presence of resources in a variety of forms factored as a crucial enabler for pro-environmental behaviour. Where the organisation was ill equipped to change their operations, actors highlighted the importance of relationships with bridging agents, intermediaries, and extension services for providing the support needed. Extension services were key to the implementation of BWI, both as an incentive as well as an enabler, as recognised by the farmers. A further key factor was the role of collaboration, both within and between institutions. Collaboration assisted in the development of a shared vision (mutual understanding, commitment and awareness of the environmental problem and how to address it), improved trust and provided access to pooled resources. Clear examples of collaboration between institutions were evident in the natural resourcebased cases (farming, fishing and food and beverage) where each organisation chose to collaborate with external (e.g. WWF South Africa) as well as internal organisations (e.g. competing organisations). Actors perceived the risks that they faced as shared risks and that the job of managing them could not be achieved independently, but were better dealt with by pooling and sharing resources, even between competitors. A theme that cuts across a number of the categories is the role of goals, targets or visioning. While embedded in a number of categories (such as demonstration, collaboration and leadership) the importance of goals in driving behaviour was clear from our actors, who frequently cited that changed behaviour was highly unlikely to be successful unless a clear description of the transformed state (future scenario or 
goal/target) was well articulated. Scenario planning was very effective in creating a vision of success facilitating buy-in of a range of actors. It was important that the actors included not only the drivers of change (WWF in this case), but also partners that included champions and other members of the sector.

Innovations and technological advancements, such as marine by-catch mitigation measures, renewable energy technology and sustainable agricultural practices allowed actors to identify new paths that could support them to realise more proenvironmental behaviours. Crucial to the spread of these technologies and practices was demonstration of 'proof of success', as these encouraged other stakeholders to follow the emerging trends and patterns. The general perception amongst actors of the finance case was the importance of demonstrating that technology was risk free, thereby encouraging cross-industry conversations, spreading the risk of taking up new technology and creating shared learning opportunities. Although there was a general consensus on the importance of innovation and technological progress, some actors noted that the degree of maturity and perceived reliability/stability of a specific technology was also an important feature that influenced its uptake. In the case of local government a range of factors impacted the diffusion of renewable energy projects and energy efficiency. These included financial feasibility, payback periods, efficiency, and generation capacity.

Incentives include both personal (e.g. scorecards) and organizational (e.g. increased market share) incentives and contributed in a few ways to shifting pro-environmental behaviours: raising awareness of issues; encouraging the identification of possible solutions; and helping organisations to become more responsive and dynamic to their 
operating environment. The use of incentives was particularly strong among larger organisations that are shaped by internal regulatory controls (food and beverage, fishing, finance and local government). In these cases, incentives include the integration of sustainability objectives into company scorecards and Key Performance Areas as well as mandated return-on-investment (ROI) periods. Incentives that promoted staff buy-in to pro-environmental policies on individual farms and smallscale fishing vessels were not as clear-cut and tended to be more integrated in training and learning-by-doing processes. Regulation is also a form of incentive and penalties a form of disincentive. Actors highlighted the importance of top-down regulatory approaches and measures that promote the development of pro-environmental behaviour. These included soft laws, hard laws, rules, standards and guidelines and their combinations were commonly highlighted in all cases. Closely linked to the use of regulation, was the need for the second- and third-party audits of actors adhering to certain standards and guidelines. For example, in the case of the BWI, second-party audits gave structure to farm procedures, encouraged internal and external accountability, and measured progress towards targets and goals - all identified as important enablers of pro-environmental behaviour. Eco-labelling and certification enrols the public to hold the entity, setting sustainability objectives, accountable, as was the case with SASSI and BWI.

Overarching macro-variables: towards a conceptual framework for proenvironmental behaviour

A key finding of this study is that these 14 variables identified across the five case studies can be summarised by three macro-variables, namely, Awareness, Motivation 
and Pathway (AMP) (Table 2). In other words, this study has identified that the three elements crucial to bring about pro-environmental behaviour are a) an awareness of key issues, b) a motivation to act and c) a way to act or pathway. The following section provides a description of each term and considers how they interact across cases.

1. The term 'awareness' is defined in this study as an understanding that society and earth systems are in fact connected, or what Anderies et al. (2004) terms 'socio-ecological systems'. In this study we adopt a definition that is broader than the simple acquisition of knowledge, but includes an altered sensibility or reframing from which individuals act. For example, for actors to shift their relationship with earth systems to one that is fundamentally interconnected and dependent, they need to reframe their current understanding and worldview to one that sees the connection between human well-being and ecosystem health. A shift in awareness by the actors under study of the impacts by society on the environment was gained from both knowledgebased and experience-based pro-environmental processes and procedures. Actors felt that both cognitive and emotional changes in their understanding were the two key factors that enabled a shift in their awareness.

2. The term motivation refers to the drive of actors to change ecologically harmful practices towards those that ensure long-term ecological sustainability. In all case studies, actors reported that they were motivated by a wide range of factors, to varying degrees and at varying periods, to becoming proenvironmental. The motivations listed in Table 1 and 2 stem from both intrinsic (broadly captured in personal norms) and extrinsic (e.g. risk, reward, reputation) values. A connection to nature, or the need to preserve nature for 
future generations, was an important, intrinsic value-driven motivation in the natural resource-based cases. On the other hand, more extrinsic value-driven motivations were found among actors from larger institutions, such as finance and local government, evolving within a more highly regulated context. Nevertheless, a motivation to act was a key factor.

3. We describe pathways as possible courses of action that enable actors to shift their practices towards those that support long-term ecological sustainability. It was clear from our analysis that there were a wide range of factors that describe the elements and importance of pathways for bringing about proenvironmental behaviours. If there was no 'way to act' then the environmental behaviour was unlikely to take hold. For example, if there is no facility to which you can take your waste, you are unlikely to recycle. The pathways observed in this research showed clear cross-cutting themes that emerged in the majority of the cases; however some had more bearing than others. For example, where actors are part of large institutions, a highly regulated industry will have fewer options in its choice of pathways, thereby limiting its options and flexibility. In a number of our cases, actors' primary motive for choosing a pathway was that it had a promise of cost-savings at least in the short-term. When this requirement was satisfied an easy business case could be made for choosing pro-environmental behaviour. Often this alignment of motives and pathways is identified and driven by green leaders or champions searching for new ways of prompting action. Other key factors include sufficient resources (human and financial), appropriate regulation, technology, incentives to undertake an available pathway or demonstration of its value. 
Awareness, motivation and pathway are thus three key variables in bringing about pro-environmental behaviour (Figure 1). Obtaining awareness through a change in sensibility reinforces a particular motivation and this motivation in turn provides the impetus to act through a pathway. In other words, an actor needs to understand and reframe to a worldview that sees the connections between human well-being and ecosystem health; they need to be motivated to act; and finally have a means or pathway to act. In some cases behaviour change takes place in the order described by the acronym, AMP, but evidence from our cases suggest that this is not always the case and could take place as PAM or MPA, depending on the context of the relationship between the actors involved, the degree of influence of each of the criteria, and the stage of transition (i.e. problem-identification phase versus implementation phase). For example in the case of the BWI, some members were motivated (to reduce environmental risk and increase profits) and then were enabled by the initiative and supporting factors. It was only after participating in the initiative that these actors developed a deeper understanding of the issues and began to shift their framing of the environmental issues associated with their traditional practices.

Each component of AMP is inter- and intra-dependent to varying degrees specific to each context and case presented. Understanding the relationships that exist between the components help to frame the conditions under which long-term proenvironmental behaviour can occur. Additionally, these components do not work in isolation but rather in a dynamic, holistic and inter-related manner, suggesting that for pro-environmental response to occur, attention cannot be focussed on satisfying one of the elements in isolation (e.g. raising awareness), but instead a more holistic approach is necessary. 
In summary, Figure 1 highlights that, despite the need for a shift in awareness, this is only one step towards a new behaviour. We argue that having a motivation to change is also required to initiate a shift towards a more pro-environmental response. In other words, there is a need to change the decision-making nexus so that issues of long-term sustainability can be integrated. Having a pathway, allows actors to respond to a new state of awareness and motivates and practically supports them to implement proenvironmental behaviour.

\section{Discussion}

A conceptual framework was constructed from an investigation of pro-environmental behaviour in five cases where interventions for behaviour change have been implemented. It is argued that previous behavioural change models and frameworks only partially explain the drivers and influences on the development of proenvironmental behaviour (Castro, 2006; Steg and Vlek, 2009; Stern et al., 1993) as they fail to integrate the theories and concepts from other disciplines that offer much to the field of behaviour science. We propose a new conceptual framework, entitled AMP, to explain the conditions under which pro-environmental behaviour occurs.

Our definition of awareness is broader than that of Kollmuss and Agyeman (2002), who define environmental awareness as a knowing of the impacts humans have on the environment. We argue that humans should have an altered sensibility or frame of reference that sees connectedness, possibilities and opportunities that could come from behaving pro-environmentally. Awareness has both a cognitive, knowledge- 
based component and an affective, perception-based component. This split was observed to originate from experiences and educational processes, a finding also described by Kollmuss and Agyeman (2002) in their study. Chawla (1998) recognises that there is no single experience that sensitizes people's awareness but rather a combination of many, some of which were also noted amongst those as presented in this paper, such as early childhood experiences and first-hand experiences of environmental destruction.

Motivation is an important driver for shifting behaviour and is in most cases a combination of vastly different factors (Steg and Vlek, 2009). This study defines motivation as 'a need to change the decision-making nexus so that the willingness to act shifts in favour of long-term sustainability'. This definition is similar to that of Wilkie (1994), who sees motivation as the reason for a behaviour, and acknowledges that the decision-making process can include a number of factors that can make up the final decision to respond. In our analysis, the motivation to act pro-environmentally arose from moral and normative concerns (Steg and Vlek, 2009), risk avoidance, and profits and rewards (Ajzen and Fishbein, 1980). The presence of moral or personal norms in our study, as defined by Schwartz (1977) as feelings of strong moral obligations that people experienced for themselves to engage in pro-social behaviour, support the Values Beliefs Norms (VBN) theory (Stern, 2000), i.e., that a decision to act pro-environmentally is based on norms developed early on in an individual's life. Social norms are defined in the Theory of Planned Behaviour (TPB) framework as perceived social pressure, that is, the expectations of significant reference persons to perform or not to perform a pro-environmental behaviour, and emanating both internally (amongst actors of the same institution) and externally (from the public or 
other institutions). The TPB framework also frames motivation around an individual's need to avoid punishments and seek rewards (Ajzen, 1991). In this study, rewards (profit) had the strongest influence on actors in almost all case studies, tipping the pivot point of the AMP framework towards actor motivation.

Motivations can also develop from individual or group values (Stern, 2000). The values observed in our findings can be split into those that are extrinsic (that are centred on external approval or rewards, e.g. wealth, material success, concern about image, social status, prestige, social power) and intrinsic that are inherently rewarding to pursue, e.g. affiliation to friends and family, connection with nature, concern for others, self-acceptance, social justice, creativity) (Schwartz, 2011). This study suggests that a combination of intrinsic and extrinsic value-driven motivations is important and can lead to long-term pro-environmental behaviour. It is also argued that while extrinsic motivations are able to shift behaviour (particularly in the shortterm), the presence of altruistic and biospheric considerations (intrinsic values) are crucial to maintain a stable and prolonged state of pro-environmental behaviour (de Groot and Steg, 2009). However this claim would need further investigation. Crompton (2010) states that humans are a lot more complex and do not simply subscribe to either an extrinsic or intrinsic set of values alone, and should therefore not be segmented into categories as such. Nonetheless he argues that it is important to understand the prioritisation of values (whether intrinsic or extrinsic), impacting on their behaviour, at that moment in time in order to facilitate behaviour change.

Actors can be aware and motivated but still not act if there is no pathway to act appropriately. The term 'pathway' is broadened in this study to identify a way of 
reaching or achieving something. Pathway can be compared with concepts in social psychology, such as Perceived Behaviour Control (PBC) in Ajzen's TPB, and 'ability' in Schwartz's Norms Activation Theory (NAT). Pathways are often practical solutions, technologies and processes people depend upon to achieve their objectives, yet they are not always easy to identify as people are often locked into a series of preexisting behaviours, habits and routines (Steg and Vlek, 2009). Creating new pathways requires substantial commitment and transaction (both financial and human capital) costs.

March (1991) highlighted how institutions, when faced with the need to change, have a tendency to 'exploit' their existing tools first, before 'exploring' new solutions. This is because exploitation involves the refining of existing practices, while exploration requires innovation that, by its nature, leads to higher degrees of institutional risktaking. As such, 'exploration' is often seen as higher risk, with longer return periods, and thus more challenging, as it requires a move beyond operational comfort-zones. However, as March warns, a primarily exploitative rather than explorative response can lead to a narrower range of solutions, which can be self-destructive over the longterm (March, 1991: 73).

This concept of exploitation is further entrenched by the tendency to be guided by existing and implicit choices locked into many features of their organisation. Thus actors seek resolutions to new challenges within previously established and proven solutions (Bateson, 1973). This includes the way they gather information, embed operational rules and practices, and incentivise certain activities. Together, this can limit the capacity of organisations to think beyond their historical 'blind spots' 
(Argyris and Schon, 1978), further encouraging a search for solutions, to challenges faced, closer to where they had been found before (Cyert and March, 1963; March and Simon, 1958).

Our conceptualisation of pathways incorporates the concept of agency, defined as the ability to act or the ability to respond (Hitlin and Elder, 2007). Agency, as understood by the Capabilities Theory, identifies the actor's values, culture and beliefs as valued 'beings' and the actor's personal experience of action as valued 'doings'. Valued beings and doings could include, but are not limited to: spending time with family; exploring creative capacities; working, play, appreciation of beauty, etc. and can be seen to be intimately connected to values that motivate specific action. The Capabilities Theory is crucial for understanding how to develop pathways best suited to the capabilities of the actors and their values. In this sense, pathways should inform their 'beings' and 'doings', rather than undermine them. In other words, it is important to develop pathways that support the agency of actors, with relation to their values and their capacities to live out these values. It is important to note that more recently the concept of agency has taken a more nuanced approach (Osman 2014a; 2014b). Osman's (2014a) essential argument is that goals are by definition prospects, thereby recognising that contingency learning connects actions with intended outcomes guided by goals. With respect to agency, the role of prospects is present in our concept of pathways, as identified under the variables, including incentives, leadership, collaboration (shared vision by stakeholders) and demonstration. These variables are goal driven, either by the end result or the visions held by the stakeholders, including leaders or champions. 
The AMP lens is considered a useful analytic lens that lends itself to understanding the full range of conditions under which pro-environmental behaviour can develop in highly variable contexts. A notable strength of this framework is that it cuts across contexts. For example, while the pathway in each context is slightly different, all contexts require a pathway regardless. The same is true for awareness and motivation. While the levels of and structure of awareness and motivation may be different in each context, the fact that the actor or groups of actors need to be aware and motivated to enable action is consistent across contexts. Thus context should be considered within each component of the framework. Context as a variable influences behaviour and can either facilitate or constrain particular behaviours and influence individual motivations (Stern, 1999; Thøgersen, 1995; Thøgersen, 2005). For example, the availability of recycling facilities, the quality of public transport, the market supply of goods, or pricing regimes can strongly affect people's choice as to whether or not to engage in a pro-environmental response (see studies by Santos, 2008; Diepen and Voogd, 2001).

This study contributes a framework that integrates multiple disciplines in a conceptual framework for pro-environmental behaviour, including theories and ideas from social psychology, sociology, organisational theory, and management science. However, due to space limitations it is not possible to locate this discussion across all bodies of literature, and thus primarily draws upon the PEB literature. Further critical review of this framework against the broader social sciences that examine change is required. Of particular interest would be the social practises theory, which de-centres individuals from analyses, and turns attention instead towards the social and 
collective organization of practices — broad cultural entities that shape individuals' perceptions, interpretations and actions within the world (Hargreaves, 2011). While this is not in conflict with the findings of this study, an in-depth exploration of the inter-relations is not the focus of this paper. Nevertheless, the AMP framework begins to cross-fertilise environmental psychology with other fields that also focus on environmentalism (Castro, 2006). It may appear that the terms and their definitions used to classify the variables in our framework are interchangeable with others that are more commonly used in psychology, but we believe that this would lose meaning, specific to the context from which our cases are derived, and the input that that discipline can offer to psychology in its attempt to understand environmentalism.

Existing frameworks that have made an important contribution to incorporating context and the cross-fertilisation of disciplines are the Behavioural Change Wheel (BCW) (Michie et al., 2011) and the Individual Social Material (ISM) Model (Darnton and Evans, 2013). There are two key differences between the BCW and the AMP approach. Firstly, the AMP framework combines capabilities and opportunities as pathways. We identified that opportunities to act can arise from the ever-changing and dynamic capability structure of actors, for example if one's capability changed from one moment to the next, there is the potential to unlock certain barriers or constraints to acting, and in this way we view a coupling of capabilities and opportunities in the AMP framework. Secondly, the AMP framework separates motivation into awareness and motivation. We view awareness as sufficiently distinct from motivation, as our concept of being aware of environmental problems and the possible solutions were seen to be an important cognitive pre-condition for developing moral personal norms (Bamberg and Möser, 2007). The third major 
difference between the AMP framework and $\mathrm{BCW}$ is how they are applied in the real world. The $\mathrm{BCW}$ is designed to link interventions to components of the behaviour system, while the AMP framework is more general in its approach to applying interventions. The ISM model on the other hand, is grounded in the understanding of individual behaviour, but sets that within its social and material contexts. The factors identified are generally comparable to those in the AMP framework, however Darnton and Evans (2013) have followed a descriptive rather than the normative categorisation of the AMP framework.

Change agents engage individuals, organisations and the environment within which they are located. A frequent challenge is the need to assess the status quo and to understand where and how to intervene. The AMP framework provides a tool for addressing both these challenges (Table 3). By assessing the levels of awareness, understanding what is motivating powerful actors, and identifying existing and potential pathways provides a useful overview of the system in which a behaviourchange intervention will be located. The framework further provides a useable tool for change agents to guide the development of environmental sustainability strategies, because it relies on broadly understood concepts, which make intuitive sense even to those unfamiliar with psychological concepts. A common shortfall of environmental strategies is that they frequently fail to consider motivation - both what currently motivates actors as well as strategies to explicitly shift their motivation (de Groot and Steg, 2009). Furthermore, many environmental strategies take a narrow view of awareness raising and are frequently limited to information campaigns, which do little to shift the framing of key actors (de Groot and Steg, 2009). Lastly, many environmental strategies fail because they only focus on pathways, and while this is 
key, this study indicates that it is only one of three factors crucial to bringing about lasting and meaningful pro-environmental behaviour.

\section{References}

Abrahamse, W., L. Steg, C. Vlek, and T. Rothengatter. 2005. "A Review of Intervention Studies Aimed at Household Energy Conservation." Journal of Environmental Psychology 25(3): 273-91.

http://www.sciencedirect.com/science/article/pii/S027249440500054X (December 18, 2013).

Ajzen, I. 1991. "The Theory of Planned Behavior." Organizational behavior and human decision processes 50(2): 179-211.

http://www.sciencedirect.com/science/article/pii/074959789190020T (December 18, 2013).

Ajzen, I. 1985. "From Intentions to Actions: A Theory of Planned Behavior." In P. D. Kuhl and J. Beckmann (ed.), Action Control, pp. 11-39. Berlin, Heidelberg: Springer.

Ajzen, I. and M. Fishbein. 1980. Understanding Attitudes and Predicting Social Behavior. Englewood Cliffs, NJ: Prentice-Hall.

Anderies, J., M. Janssen, and E. Ostrom. 2004. "A Framework to Analyze the Robustness of Social-Ecological Systems from an Institutional Perspective." Ecology and Society 9(1): 18. http://www.public.asu.edu/ majansse/pubs/es2004a.pdf (December 05, 2013).

Argyris, C., and D. Schon. 1978. Organizational Learning: A Theory of Action Approach. Reading, MA: Addision Wesley. $\mathrm{http}: / /$ scholar.google.com/scholar?q=Argyris+and+Schon+1978\&btnG=\&hl=en\&as_s $\mathrm{dt}=0,5 \# 0$ (December 02, 2013).

Atkinson, P., and M. Hammersley. 1994. "Ethnography and Participant Observation." In N.K. Denzin and Y.S. Lincoln (eds.), Handbook of Qualitative Research, New Delhi: Sage.

Bamberg, S., and G. Möser. 2007. "Twenty Years after Hines, Hungerford, and Tomera: A

New Meta-Analysis of Psycho-Social Determinants of pro-Environmental Behaviour." Journal of Environmental Psychology 27(1): 14-25.

http://www.sciencedirect.com/science/article/pii/S0272494406000909 (October 3, 2013).

Bamberg, S., and P. Schmidt. 2003. "Incentives, Morality, Or Habit?: Predicting Students' Car Use for University Routes With the Models of Ajzen, Schwartz, and Triandis." Environment \& Behavior 35(2): 264-85.

http://eab.sagepub.com/cgi/doi/10.1177/0013916502250134 (September 16, 2013).

Bandura, A. 1989. "Human Agency in Social Cognitive Theory." American Psychologist 44(9): 1175-84.

Barnosky, A.D., Hadly, E.A., and J. Bascompte. 2012. “Approaching a State Shift in Earth's Biosphere." Nature 486(7401): 52-58.

http://www.nature.com/nature/journal/v486/n7401/full/nature11018.html.

Bateson, P.P.G. 1973. "Preferences for Familiarity and Novelty: A Model for the Simultaneous Development of Both." Journal of theoretical biology 41(2): 249-59. http://www.sciencedirect.com/science/article/pii/0022519373901173 (December 1, 2013). 
Blake, J. 1999. “Overcoming the 'value-action Gap' in Environmental Policy: Tensions between National Policy and Local Experience.” Local Environment 4(3): 257-78. http://dx.doi.org/10.1080/13549839908725599 (January 31, 2014).

BWI. 2012. Biodiversity \& Wine Initiative. WWF South Africa.

http://www.wwf.org.za/what_we_do/outstanding_places/fynbos/biodiversity wine initiative/index.cfm. (January 31, 2014).

CAPE. 2009. Biodiversity and Wine Initiative (BWI): Stewardship within an Industry Context. Cape Town: CAPE.

http://www.capeaction.org.za/index.php?C=casestudy\&A=display\&id=425.

Castro, P. 2006. "Applying Social Psychology to the Study of Environmental Concern and Environmental Worldviews : Contributions from the Social Representations Approach." 266(March): 247-66.

CCT. 2011. Moving Mountains; Cape Town's Action Plan for Energy and Climate Change. Cape Town: Environmental Management Department, City of Cape Town.

Chawla, L. 1998. "Significant Life Experiences Revisited: A Review of Research on Sources of Environmental Sensitivity." The Journal of Environmental Education. 29 (3): 1121. http://www.tandfonline.com/doi/abs/10.1080/00958969809599114 (December 16, 2013).

Conley, A. and M.A. Moote. 2003. "Evaluating Collaborative Natural Resource Management." Society and Natural Resources 16: 371-386.

Crompton, T. 2010. Common Cause: The Case for Working with our Cultural Values. London: WWF-UK.

Cyert, R.M. and J. March. 1963. “A Behavioral Theory of the Firm.” University of Illinois at Urbana-Champaign's Academy for Entrepreneurial Leadership Historical Research Reference in Entrepreneurship. http://papers.ssrn.com/sol3/Delivery.cfm?abstractid=1496208 (December 15, 2013).

Darnton, A. and D. Evans. 2013. Influencing Behaviours: A Technical Guide to the ISM Tool. Edinburgh: Scottish Government.

Darnton, A. 2008. GSR Behaviour Change Knowledge Review: Practical Guide. London: Government Social Research Unit.

Diepen, A.V. and H. Voogd. 2001. "Sustainability and Planning: Does Urban Form Matter?" International Journal of Sustainable Development 4(1): 59-74.

http://inderscience.metapress.com/index/cm59n92w5e77bvbu.pdf (December 18, 2013).

Duncan, J. 2010. "Do We Need to Rethink Growth? Can We Have Unlimited Economic Growth in a World of Finite Resources." Fundamentals: The Quarterly News Magazine of Old Mutual Investment Group (South Africa): 10-12. http://www.oldmutual.co.za/documents/OMIGSA/FundamentalsQ42012.pdf (May 14, 2013).

de Groot, J. M. and L. Steg. 2009. "Mean or Green: Which Values Can Promote Stable proEnvironmental Behavior?" Conservation Letters 2(2): 61-66. http://doi.wiley.com/10.1111/j.1755-263X.2009.00048.x (November 4, 2013).

Fransson, N. and T. Gärling. 1999. "Environmental Concern: Conceptual Definitions, Measurement Methods, and Research Findings.” Journal of Environmental Psychology 19(4): 369-82. http://www.sciencedirect.com/science/article/pii/S027249449990141X (January 29, 2014).

Gifford, R. 2008. “Toward a Comprehensive Model.” In A. Biel, D. Eek, T. Gärling, and M. Gustafsson (eds.), New Issues and Paradigms in Research on Social Dilemmas, pp. 265-79. US: Springer US. 
Heberlein, T.A. 1977. "Norm Activation and Environmental Action: A Rejoinder to RE Dunlap and KD Van Liere." Journal of Social Issues 33(3): 207-11. http://onlinelibrary.wiley.com/doi/10.1111/j.1540-4560.1977.tb01892.x/abstract (December 2, 2013).

Hines, J.M., H.R. Hungerford, and A.N. Tomera. 1987. "Analysis and Synthesis of Research on Responsible Environmental Behavior: A Meta-Analysis." The Journal of Environmental Education 18(2): 1-8. http://dx.doi.org/10.1080/00958964.1987.9943482 (September 29, 2013).

Hitlin, S. and G.H. Elder. 2007. "Time, Self, and the Curiously Abstract Concept of Agency." Sociological Theory 25(2): 170-91. http://stx.sagepub.com/lookup/doi/10.1111/j.1467-9558.2007.00303.x (December 05, 2013).

Kollmuss, A. and J. Agyeman. 2002. "Mind the Gap : Why Do People Act Environmentally and What Are the Barriers to pro- Environmental Behavior ?" Environmental Education Research 8(3): 239-260.

Layder, D. 1998. Sociological Practice: Linking Theory and Social Research. London: Sage Publications Ltd.

Lehman, P.K., and E.S. Geller. 2005. "Behavior Analysis and Environmental Protection: Accomplishments and Potential for More." Behavior and Social Issues 13:13-32. http://ojphi.org/ojs/index.php/bsi/article/view/33 (December 05, 2013).

March, J.G. 1991. "Exploration and Exploitation in Organizational Learning." Organizational Science 2(1): 71-87. http://www.analytictech.com/mb874/papers/march.pdf.( December 05, 2013).

March, J.G., and H.A. Simon. 1958. Organizations. New York: John Wiley \& Sons.

Mayoux, L. 2006. 'Quantitative, Qualitative or Participatory? Which Method, for What and When?” In D. Vandanna and R. Potter (eds.), Doing Development Research, pp.324. London: Sage.

Michie, S., M.M. van Stralen, and R.West. 2011. "The Behaviour Change Wheel: A New Method for Characterising and Designing Behaviour Change Interventions." Implementation Science : IS 6(1): 42.

http://www.pubmedcentral.nih.gov/articlerender.fcgi?artid=3096582\&tool=pmcentrez \&rendertype=abstract (September 21, 2013).

Morgan, T. 2013. Perfect Storm: Energy, Finance and the End of Growth. London: Sage Publications.

http://ftalphaville.ft.com/files/2013/01/Perfect-Storm-LR.pdf. (September 21, 2013).

Neyland, D. 2008. Organizational Ethnography. London: Sage Publications.

Old Mutual Plc. 2013. Old Mutual| Responsible Business. http://www.oldmutual.com/rb/index.jsp (February 2, 2013).

Osman, M. 2014a. "What are the essential cognitive requirements for prospection (thinking about the future)?" Frontiers in Psychology 5: 1-4.

Osman, M. 2014b. Future-Minded: The Psychology of Agency and Control. London: Palgrave Macmillan.

Pence, G. 2011. "Contribution of C.A.P.E. Business and Biodiversity Initiatives to Conservation of Critical Biodiversity, Landscape Connectivity and Ecological Support Areas, 2010”. Baseline Report. Kirstenbosch, Cape Town: Conservation South Africa.

Ramsey, C.E. and R.E. Rickson. 1976. "Environmental Knowledge and Attitudes." The Journal of Environmental Education 8(1): 10-18. http://dx.doi.org/10.1080/00958964.1976.9941552.( December 05, 2013). 
Rockström, J., W. Steffen, K. Noone, A. Persson, et al. 2009. “A Safe Operating Space for Humanity." Nature 461(7263): 472-75.

Rogers, E.M. 1962. Diffusion of Innovations. New York: Free Press of Glencoe.

Santos, G. 2008. “The London Experience.” In E. Verhoef, M. Bliemer, L. Steg, and B. Van Wee (eds.), Pricing in Road Transport. A Multi-Disciplinary Perspective, pp. 273-292. Northampton: Edward Elgar Publisher.

Schultz, P.W., S. Oskamp and T. Mainieri. 1995. "Who Recycles and When? A Review of Personal and Situational Factors." Journal of environmental psychology 15(2): 10521. http://www.sciencedirect.com/science/article/pii/0272494495900195 (December 02, 2013).

Schwartz, S.H. 2011. "Studying Values: Personal Adventure, Future Directions." Journal of Cross-Cultural Psychology 42(2): 307-19.

http://jcc.sagepub.com/content/42/2/307.short (August 12, 2013).

Schwartz, S.H. 1977. "Normative Influences on Altruism.” In L. Berkowitz (ed.), Advances in Experimental Social Psychology. New York: Academic Press.

Sen, A. 1999. Development as Freedom. Oxford University Press.

Shove, E. 2010. "Beyond the ABC: climate change policy and theories of social change." Environmental Planning A 42: 1273-1285.

Steg, L. and C. Vlek. 2009. "Encouraging pro-Environmental Behaviour: An Integrative Review and Research Agenda." Journal of Environmental Psychology 29(3): 309-17. http://linkinghub.elsevier.com/retrieve/pii/S0272494408000959 (September 16, 2013).

Stern, P. 2000. "New Environmental Theories: Toward a Coherent Theory of Environmentally Significant Behavior." Journal of Social Issues 56(3): 407-24.

Stern, P., T. Dietz, and L. Kalof. 1993. "Value Orientations, Gender, and Environmental Concern." Environment and behavior 25: 322.

http://eab.sagepub.com/content/25/5/322.short (December 18, 2013).

Stern, P.C. 1999. "Information, Incentives, and Proenvironmental Consumer Behavior." Journal of Consumer Policy 22(4): 461-78. http://link.springer.com/article/10.1023/A:1006211709570 (December 18, 2013).

Taylor-powell, E. 1998. "Questionnaire Design : Asking Questions with a Purpose." University of Wisconsin-extension. http://learningstore.uwex.edu/assets/pdfs/g36582.pdf (May 2013).

Thøgersen, J. 1995. "Understanding of Consumer Behaviour as a Prerequisite for Environmental Protection.” Journal of Consumer Policy 18(4): 345-85. http://link.springer.com/article/10.1007/BF01024160 (December 18, 2013).

Thøgersen, J. 2005. "How May Consumer Policy Empower Consumers for Sustainable Lifestyles?" Journal of Consumer Policy 28(2): 143-77. http://link.springer.com/10.1007/s10603-005-2982-8 (December 12, 2013).

Vlek, C. 2000. "Essential Psychology for Environmental Policy Making." International Journal of Psychology 35(2): 153-67. http://dx.doi.org/10.1080/002075900399457 (January 29, 2014).

Wilkie, L. 1994. Consumer Behavior. $3^{\text {rd }}$ Edition. New York: Wiley. http://books.google.co.za/books/about/Consumer_behavior.html?id=9ZfdfbDey0C\&pgis=1 (December 18, 2013).

Wilson, M., L. Steg, and C. Vlek. 2009. "Encouraging pro-Environmental Behaviour: An Integrative Review and Research Agenda." Journal of Environmental Psychology 29(3): 309-17. http://www.sciencedirect.com/science/article/pii/S0272494408000959 (September 29, 2013). 
Table 1: The conditions and their classification that determine pro-environmental behaviour as identified in five cases including the food and beverage, farming, fishing, finance and local government ( $\mathrm{X}=$ present; - = not present)

\begin{tabular}{|c|c|c|c|c|c|c|c|}
\hline Category & Description & Variables & Beverage & Farming & Fishing & Finance & Local government \\
\hline \multirow{2}{*}{ Knowledge } & \multirow{2}{*}{$\begin{array}{l}\text { Facts, information, and skills } \\
\text { acquired through experience or } \\
\text { education. }\end{array}$} & Education & $\mathrm{X}$ & $\mathrm{X}$ & $\mathrm{X}$ & $\mathrm{X}$ & $\mathrm{X}$ \\
\hline & & Research and development* & $\mathrm{X}$ & - & $\mathrm{X}$ & $\mathrm{X}$ & $\mathrm{X}$ \\
\hline \multirow[b]{2}{*}{ Experience } & \multirow{2}{*}{$\begin{array}{l}\text { Comprising knowledge of or skill } \\
\text { of something or some event } \\
\text { gained through involvement in or } \\
\text { exposure to that thing or event. }\end{array}$} & $\begin{array}{l}\text { Early childhood experiences } \\
\text { in Nature }\end{array}$ & - & $\mathrm{X}$ & $X$ & - & - \\
\hline & & $\begin{array}{l}\text { First-hand experience of an } \\
\text { environmental/economic } \\
\text { crisis }\end{array}$ & $\mathrm{X}$ & $\mathrm{X}$ & $\mathrm{X}$ & $\mathrm{X}$ & $\mathrm{X}$ \\
\hline \multirow{3}{*}{$\begin{array}{l}\text { Moral / personal } \\
\text { norms }\end{array}$} & \multirow{3}{*}{$\begin{array}{l}\text { Feelings of strong moral } \\
\text { obligations that people } \\
\text { experienced for themselves to } \\
\text { engage in pro-social behaviour. }\end{array}$} & Passion for Nature & - & $\mathrm{X}$ & $\mathrm{X}$ & - & - \\
\hline & & Feels good/feels bad & - & $\mathrm{X}$ & $\mathrm{X}$ & $\mathrm{X}$ & $\mathrm{X}$ \\
\hline & & Moral imperative & $\mathrm{X}$ & $\mathrm{X}$ & $\mathrm{X}$ & $\mathrm{X}$ & $\mathrm{X}$ \\
\hline \multirow{5}{*}{ Social norms } & \multirow{5}{*}{$\begin{array}{l}\text { The perceived social pressure, } \\
\text { that is, the expectations of } \\
\text { significant reference persons to } \\
\text { perform or not to perform a } \\
\text { behaviour }\end{array}$} & Peer pressure & $\mathrm{X}$ & $\mathrm{X}$ & $X$ & $\mathrm{X}$ & $\mathrm{X}$ \\
\hline & & Public pressure & $\mathrm{X}$ & - & $X$ & $\mathrm{X}$ & $\mathrm{X}$ \\
\hline & & Credibility & $\mathrm{X}$ & $\mathrm{X}$ & $\mathrm{X}$ & $X$ & $\mathrm{X}$ \\
\hline & & Recognition & $\mathrm{X}$ & $\mathrm{X}$ & $\mathrm{X}$ & $\mathrm{X}$ & $\mathrm{X}$ \\
\hline & & $\begin{array}{l}\text { Business ethos and } \\
\text { corporate culture }\end{array}$ & $\mathrm{X}$ & $\mathrm{X}$ & $\mathrm{X}$ & $\mathrm{X}$ & - \\
\hline \multirow{3}{*}{$\begin{array}{l}\text { Risk reduction / } \\
\text { avoidance }\end{array}$} & \multirow{3}{*}{$\begin{array}{l}\text { Seeking to mitigate or avoid risks } \\
\text { that arise from regulatory, macro, } \\
\text { micro, or natural environments. }\end{array}$} & $\begin{array}{l}\text { Macro- and micro- } \\
\text { environment risk }\end{array}$ & $\mathrm{X}$ & $\mathrm{X}$ & $\mathrm{X}$ & $\mathrm{X}$ & $\mathrm{X}$ \\
\hline & & Environmental risk & - & $\mathrm{X}$ & $\mathrm{X}$ & $\mathrm{X}$ & $\mathrm{X}$ \\
\hline & & Regulatory risk & $\mathrm{X}$ & - & $X$ & $\mathrm{X}$ & $X$ \\
\hline \multirow[t]{4}{*}{ Profit motive } & \multirow{4}{*}{$\begin{array}{l}\text { Seeking to benefit oneself and/or } \\
\text { shareholders by maximizing } \\
\text { profits. }\end{array}$} & Increasing profits & $\mathrm{X}$ & $\mathrm{X}$ & $\mathrm{X}$ & $\mathrm{X}$ & $\mathrm{X}$ \\
\hline & & Marketing/brand advantage & $\mathrm{X}$ & $\mathrm{X}$ & $X$ & $\mathrm{X}$ & $\mathrm{X}$ \\
\hline & & First mover advantage & $X$ & - & - & $X$ & $X$ \\
\hline & & Economic efficiency & $\mathrm{X}$ & - & $\mathrm{X}$ & $\mathrm{X}$ & $X$ \\
\hline
\end{tabular}




\begin{tabular}{|c|c|c|c|c|c|c|c|}
\hline & & Investor & $\mathrm{x}$ & $\mathrm{x}$ & $\mathrm{X}$ & $\mathrm{x}$ & $\mathrm{X}$ \\
\hline \multirow{2}{*}{$\begin{array}{l}\text { Low-hanging } \\
\text { fruits }\end{array}$} & \multirow{2}{*}{$\begin{array}{l}\text { Targets or goals that are easily } \\
\text { achievable and which do not } \\
\text { require a lot of effort. }\end{array}$} & Easy-win & $\mathrm{X}$ & $\mathrm{X}$ & $\mathrm{X}$ & $\mathrm{x}$ & $\mathrm{X}$ \\
\hline & & Voluntary agreement & $\mathrm{x}$ & $\mathrm{x}$ & $\mathrm{X}$ & $\mathrm{x}$ & $\mathrm{X}$ \\
\hline \multirow{2}{*}{ Leadership } & \multirow{2}{*}{$\begin{array}{l}\text { An actor who guides or directs } \\
\text { others }\end{array}$} & Green champions & $\mathrm{x}$ & $\mathrm{x}$ & $\mathrm{X}$ & $\mathrm{x}$ & $\mathrm{X}$ \\
\hline & & Leaders & $\mathrm{x}$ & $\mathrm{x}$ & $\mathrm{X}$ & $\mathrm{x}$ & $\mathrm{X}$ \\
\hline \multirow[t]{3}{*}{ Resources } & \multirow{3}{*}{$\begin{array}{l}\text { Human, economic, natural capital } \\
\text { or supply from which benefit is } \\
\text { produced }\end{array}$} & $\begin{array}{l}\text { Bridging agents, } \\
\text { intermediaries, extension } \\
\text { services }\end{array}$ & $\mathrm{x}$ & X & $\mathrm{X}$ & $\mathrm{x}$ & $\mathrm{X}$ \\
\hline & & Financial resources & $\mathrm{x}$ & $\mathrm{x}$ & $\mathrm{x}$ & $\mathrm{x}$ & $\mathrm{X}$ \\
\hline & & Labour & $\mathrm{x}$ & $\mathrm{x}$ & $\mathrm{X}$ & $\mathrm{x}$ & $\mathrm{X}$ \\
\hline \multirow{3}{*}{ Collaboration } & \multirow{3}{*}{$\begin{array}{l}\text { To work with another person or } \\
\text { group in order to achieve or do } \\
\text { something }\end{array}$} & Shared vision & $\mathrm{x}$ & $\mathrm{x}$ & $\mathrm{X}$ & $\mathrm{x}$ & $\mathrm{x}$ \\
\hline & & Trust & $\mathrm{x}$ & $\mathrm{x}$ & $\mathrm{x}$ & $\mathrm{x}$ & $\mathrm{X}$ \\
\hline & & Pooled resources & - & $\mathrm{x}$ & $\mathrm{X}$ & $\mathrm{x}$ & $\mathrm{X}$ \\
\hline \multirow{2}{*}{$\begin{array}{l}\text { Technology \& } \\
\text { Innovation }\end{array}$} & \multirow[b]{2}{*}{ Solutions becoming viable } & Technology and innovation & - & $\mathrm{x}$ & $\mathrm{x}$ & $\mathrm{x}$ & $\mathrm{X}$ \\
\hline & & $\begin{array}{l}\text { Dynamic of the supply } \\
\text { chains environment }\end{array}$ & $\mathrm{x}$ & $\mathrm{X}$ & $\mathrm{X}$ & $\mathrm{x}$ & $\mathrm{X}$ \\
\hline Demonstration & $\begin{array}{l}\text { Showing by reason or proof, } \\
\text { explaining or making clear by use } \\
\text { of examples or projects. }\end{array}$ & Demonstration projects & $\mathrm{X}$ & $\mathrm{X}$ & - & $\mathrm{x}$ & $\mathrm{X}$ \\
\hline Incentive & $\begin{array}{l}\text { A process or structure adopted to } \\
\text { motivate actors. }\end{array}$ & $\begin{array}{l}\text { Incentives, KPI's, score } \\
\text { cards, return on investment } \\
\text { (ROI) periods }\end{array}$ & X & - & - & $\mathrm{X}$ & $\mathrm{X}$ \\
\hline \multirow{4}{*}{ Regulation } & \multirow{4}{*}{$\begin{array}{l}\text { Regulation creates, limits, or } \\
\text { constrains a right, creates or } \\
\text { limits a duty, or allocates a } \\
\text { responsibility }\end{array}$} & Reporting & $\mathrm{X}$ & $\mathrm{x}$ & $\mathrm{x}$ & $\mathrm{x}$ & $\mathrm{X}$ \\
\hline & & Audits & $\mathrm{X}$ & $\mathrm{x}$ & $\mathrm{x}$ & $\mathrm{x}$ & $\mathrm{X}$ \\
\hline & & Legislation & $\mathrm{X}$ & $\mathrm{X}$ & $\mathrm{X}$ & $\mathrm{X}$ & $\mathrm{X}$ \\
\hline & & $\begin{array}{l}\text { Environmental certification } \\
\text { and voluntary mechanisms }\end{array}$ & $\mathrm{X}$ & $\mathrm{X}$ & $\mathrm{X}$ & $\mathrm{X}$ & $\mathrm{X}$ \\
\hline
\end{tabular}


*Research conducted to better understand the "socio-ecological" challenges and develop solutions

Table 2: Three overarching macro-variables: Awareness (A), Motivation (M) and Pathway (P), which summarise the 14 categories promoting pro-environmental behaviour as identified in five cases including the food and beverage, farming, fishing, finance and local government.

\begin{tabular}{|l|l|l|}
\hline $\begin{array}{l}\text { Awareness (A) understanding that } \\
\text { society and earth systems are } \\
\text { connected }\end{array}$ & $\begin{array}{l}\text { Motivation (M) personal and operational drivers that } \\
\text { The } \\
\text { encourage an individual or organisation to } \\
\text { respond to new levels of Awareness } \\
\text { Knowledge }\end{array}$ & $\begin{array}{l}\text { Pathway (P) practical solutions and } \\
\text { opportunities that facilitate actual } \\
\text { change }\end{array}$ \\
\hline Experience & Social/personal norms & Leadership \\
\hline & Risk reduction/avoidance & Resources \\
\hline & Profits & Collaboration \\
\hline & Low-hanging fruits & Technology and Innovation \\
\hline & & Demonstration \\
\hline & & Regulation \\
\hline
\end{tabular}
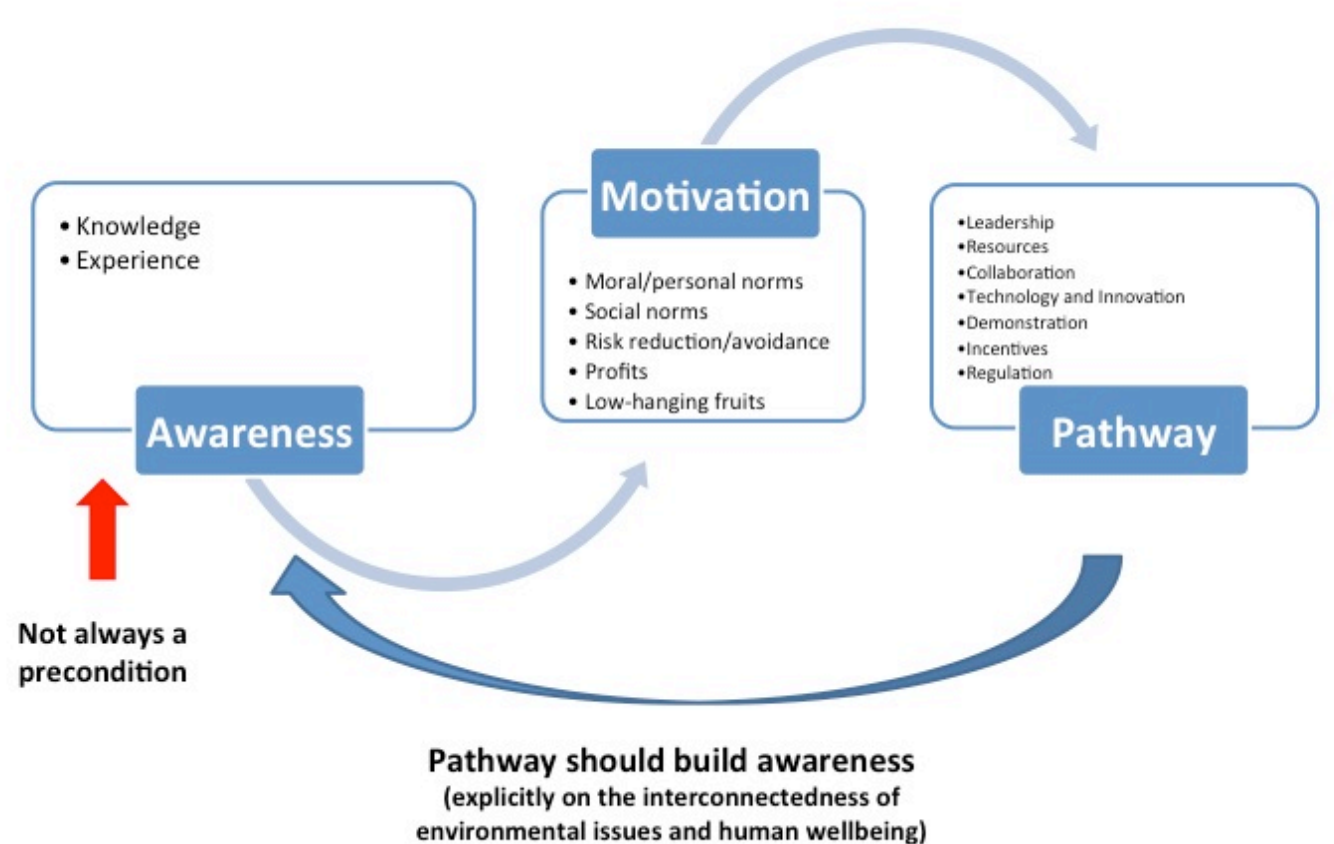

Figure 1: Summarized, generalized AMP conceptual framework for pro-environmental behaviour. It is important to note that the framework is not linear - can start at any point, i.e. awareness, motivation or pathway.

Table 3: Assessment and strategy application of the AMP framework

\begin{tabular}{|c|c|c|}
\hline & Assessment & Strategic outcome \\
\hline Awareness (A) & $\begin{array}{l}\text { - What is the knowledge of key environmental } \\
\text { issues by powerful or influential actors, } \\
\text { organisation or sector? } \\
\text { - What is the predominant worldview of these } \\
\text { actors? }\end{array}$ & $\begin{array}{l}\text { Actors have a worldview that sees the } \\
\text { connection between human well-being } \\
\text { and ecosystem health }\end{array}$ \\
\hline
\end{tabular}




\begin{tabular}{|l|l|l|}
\hline Motivation (M) & $\begin{array}{l}\text { - What motivates powerful/Influential actors? } \\
\text { What drives their key decisions? }\end{array}$ & $\begin{array}{l}\text { Actors are motivated to act in a pro- } \\
\text { environmental manner and this } \\
\text { motivation is sustained over time. }\end{array}$ \\
\hline Pathway (P) & $\begin{array}{l}\text { - What solutions exist to address the key issue } \\
\text { (e.g. technology, practises etc.)? } \\
\text { - What resources are available? } \\
\text { - What incentives exist? }\end{array}$ & $\begin{array}{l}\text { Powerful or influential actors have the } \\
\text { capability (skill, opportunity and } \\
\text { resources), technology/practise, and } \\
\text { enabling environment to act. }\end{array}$ \\
\hline
\end{tabular}

